\title{
Solitary Metastasis of Renal Cell Carcinoma to the Adrenal Gland: Treatment Outcomes Following Laparoscopic Retroperitoneal Adrenalectomy
}

\author{
(1) Cameron Parkin 1,2, (1) George Acland1, (1) Mark Louie-Johnsun1,3,4 \\ 1Department of Urology, Gosford Hospital, Central Coast Local Health District, New South Wales, Australia \\ 2School of Medicine, The University of Notre Dame, New South Wales, Australia \\ ${ }^{3}$ School of Medicine and Public Health, University of Newcastle, New South Wales, Australia \\ ${ }^{4}$ Gosford Private Hospital, New South Wales, Australia
}

\section{What's known on the subject? and What does the study add?}

Solitary adrenal metastasis from primary renal cell carcinoma is rare, particularly when occurring in the contralateral adrenal gland. Traditionally an open adrenalectomy has been the gold-standard treatment. This study introduces the use of a retroperitoneal laparoscopic approach and reports on the perioperative and oncological outcomes of four patients who underwent this technique.

\begin{abstract}
Objective: The oncological and survival benefits of adrenalectomy in patients with solitary adrenal metastasis following nephrectomy for renal cell carcinoma (RCC) through the use of a retroperitoneal laparoscopic technique are not yet known. This study aimed to report the outcomes of patients who have undergone laparoscopic retroperitoneal adrenalectomy for a solitary adrenal metastasis from primary RCC.

Materials and Methods: From a prospectively collected single-surgeon database of 307 upper tract retroperitoneal laparoscopic cases, four patients underwent laparoscopic retroperitoneal adrenalectomy for solitary RCC metastasis between January 2015 and August 2020. Their clinical history, pathology, and perioperative and oncological outcomes were reviewed.

Results: The mean age of the patients at initial nephrectomy was $61 \pm 10.8$ years, and all had negative surgical margins. The median time to diagnosis of adrenal metastasis was 52.6 (13.6-121.0) months. In three patients, metastasis to the adrenal gland contralateral to the original nephrectomy was identified. All patients underwent retroperitoneal laparoscopic adrenalectomy, which confirmed metastatic RCC. All surgical margins were free of disease. Within 90 days post-adrenalectomy, only one Clavien-Dindo grade 1 complication was recorded. One of the patients died from widespread metastatic disease 45 months following his adrenalectomy. The remaining three patients remain cancer-free.

Conclusion: Solitary metastatic adrenal recurrence from RCC is rare. To our knowledge, this is the largest study that describes a laparoscopic retroperitoneal approach in the removal of solitary adrenal metastatic RCC. This minimally invasive approach can be performed safely with low perioperative complications and encouraging oncological outcomes.
\end{abstract}

Keywords: Renal cell carcinoma, adrenal metastasis, laparoscopic retroperitoneal adrenalectomy, outcomes

\section{Introduction}

Renal cell carcinoma (RCC) is the seventh most diagnosed malignancy in Australia with approximately 4,000 new cases annually (1). RCC can be an aggressive cancer because 1 in 3 patients develop distant metastatic disease following curative- intent surgical extirpation (2). Common sites of RCC metastasis include the lymph nodes, liver, lung, brain, and bones (3). Metastasis to the adrenal glands following nephrectomy is uncommon, and contralateral adrenal metastatic disease is particularly rare. In autopsies of 400 patients who have undergone nephrectomy for RCC, only $2.5 \%$ of the patients

Correspondence: Cameron Parkin MD, Department of Urology, Gosford Hospital, Central Coast Local Health District, School of Medicine, The University of Notre Dame, New South Wales, Australia

Phone: (02) $43202111 \quad$ E-mail: cameronjparkin@gmail.com ORCID-ID: orcid.org/0000-0001-6294-2368

Received: 30.12 .2020 Accepted: 21.02 .2021

Cite this article as: Parkin C, Acland G, Louie-Johnsun M. Solitary Metastasis of Renal Cell Carcinoma to the Adrenal Gland: Treatment Outcomes Following Laparoscopic Retroperitoneal Adrenalectomy. J Urol Surg 2021;8(3):185-190.

๑Copyright 2021 by the Association of Urological Surgery / Journal of Urological Surgery published by Galenos Publishing House. 
were identified to have metastatic disease in the contralateral adrenal gland (4).

For benign adrenal disorders requiring adrenalectomy, laparoscopic surgery is now the gold standard and can be performed through transperitoneal or retroperitoneal approaches (5). An open approach is still advocated for malignant adrenal disease (6). The retroperitoneal laparoscopic approach is a new technique that has potential advantages of lower morbidity compared with both open and transperitoneal procedures. Studies have shown that the retroperitoneal approach, where intraperitoneal organs are avoided, results in reduced operating time, reduced blood loss, superior postoperative pain scores, and reduced length of stay (6-8). However, only a few studies have described the use of this retroperitoneal approach in performing adrenalectomy for solitary metastatic RCC in the adrenal gland.

At our center, a laparoscopic fellowship-trained urological surgeon performs on average 27 retroperitoneal laparoscopic upper tract cases per year over the last 11 years and performs laparoscopic adrenalectomy also through a retroperitoneal approach.

\section{Materials and Methods}

We reviewed a prospectively collected single-surgeon series of retroperitoneal laparoscopic upper tract cases and identified four patients undergoing laparoscopic retroperitoneal adrenalectomy for solitary adrenal metastasis from RCC between 2015 and 2020. Demographic, clinical, and histopathological data were retrospectively collected from electronic health records.

Ethics approval was obtained from the Hunter New England Human Research Ethics Committee in conjunction with the Central Coast Local Health District (2020/ETH02908).

Our technique for laparoscopic retroperitoneal adrenalectomy is similar to previous descriptions $(9,10)$. The patient is placed in a lateral decubitus position with the operating table manipulated to maximize the distance between the $12^{\text {th }}$ rib and the iliac crest. A four-port retroperitoneal technique is used with an initial 1.5$\mathrm{cm}$ skin incision made below the inferior edge of the tip of the $12^{\text {th }}$ rib, where the muscle and fascial layers are bluntly entered with finger dissection, to form a space for balloon insufflation under vision, creating the retroperitoneal working space using a Spacemaker ${ }^{\mathrm{TM}}$ Pro Access Dissector System. The balloon is deflated, and a laparoscope is placed thereafter. Three other laparoscopic ports are then placed parallel inferiorly to the $12^{\text {th }}$ rib in line with the primary port site incision (Figure 1). A 10$\mathrm{mm}$ Medtronic Endo Retract II is used, Gerota's fascia is incised, and the perinephric fat is dissected around the adrenal gland in a "no-touch technique" of the adrenal gland. The adrenal vein is double clipped and then divided, and the adrenal gland is removed with a 10-mm Covidien Endocatch bag.

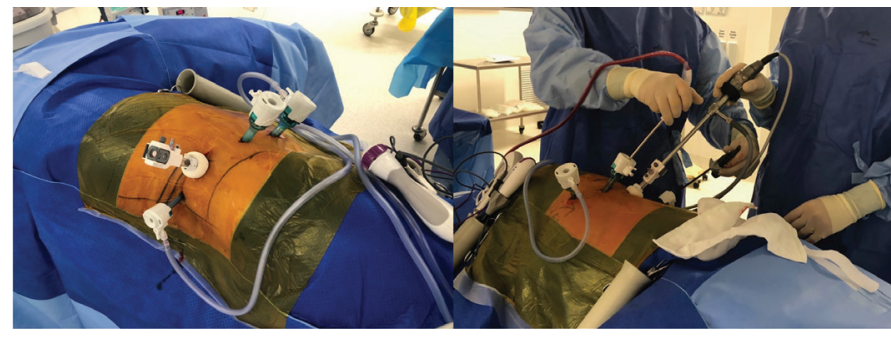

Figure 1. Laparoscopic right retroperitoneal adrenalectomy approach: fourport technique. The patient is placed in the lateral decubitus position. The $12^{\text {th }}$ rib and iliac crest are marked previously. The port for the balloon insufflation device that creates the working space in the retroperitoneum is placed 1.5 $\mathrm{cm}$ below the $12^{\text {th }}$ rib. Two $10-\mathrm{mm}$ ports are placed anteriorly and parallel with the iliac crest. These are used for dissection and retraction. A 5-mm port is placed posterior to the camera port, in line with the posterior axillary line

\section{Results}

The operative and histopathological features of the primary RCC removed for the patients with subsequent adrenal metastatic disease are summarized in Table 1. Three of the four patients had undergone laparoscopic radical nephrectomy, and one patient had an open partial nephrectomy. All were pathologically confirmed clear cell RCC with clear surgical margins.

The mean age of the four patients at initial nephrectomy was $61 \pm 10.8$ years. The interval from nephrectomy to the diagnosis of adrenal metastasis was 52.6 (13.6-121.0) months, as outlined in Table 2. Three of the four patients were identified to have metastatic disease in the adrenal gland on the contralateral side to their initial nephrectomy.

All four patients were asymptomatic when metastatic diseases were identified by routine surveillance computer tomography. Figure 2 displays representative slices of the initial radiology of the solitary adrenal tumors identified in four patients.

All four patients underwent retroperitoneal laparoscopic adrenalectomy. Perioperative outcomes are described in Table 3. The mean age and body mass index of the patients was $70 \pm 6.2$ years and $38.3 \pm 4.3 \mathrm{~kg} / \mathrm{m}^{2}$, respectively. The mean operating time was $140 \pm 8.7 \mathrm{~min}$. The mean estimated blood loss was $163 \pm 124.4 \mathrm{~mL}$, and no blood transfusions and open conversions were required. The mean hospital length of stay was $2.3 \pm 0.4$ days. The procedures in three of the four patients were partly performed by a trainee.

Postoperative complications were classified based on the classification. Only one Clavien-Dindo grade 1 complication was recorded within the 90-day postoperative period. This involved superficial wound dehiscence at a laparoscopic port site that required a community nurse for wound care. Antibiotics were not prescribed. The wound was inspected 2 weeks postoperatively and had healed by secondary intention. 


\begin{tabular}{|c|c|c|c|c|c|c|c|c|}
\hline Patient & Age & Sex & $\begin{array}{l}\text { Year of } \\
\text { operation }\end{array}$ & Operation & Histopathology & $\begin{array}{l}\text { ISUP } \\
\text { grade }\end{array}$ & $\begin{array}{l}\text { Staging } \\
\text { (TNM) }\end{array}$ & $\begin{array}{l}\text { Surgical } \\
\text { margins }\end{array}$ \\
\hline 2 & 75 & $M$ & 2015 & $\begin{array}{l}\text { Right retroperitoneal } \\
\text { laparoscopic nephrectomy }\end{array}$ & $\begin{array}{l}\text { Clear cell renal cell } \\
\text { carcinoma }\end{array}$ & 3 & $\begin{array}{l}\mathrm{pT} 1 \mathrm{a}, \mathrm{Nx} \\
\mathrm{Mx}\end{array}$ & Clear \\
\hline 3 & 55 & M & 2008 & $\begin{array}{l}\text { Right transperitoneal } \\
\text { nephrectomy }\end{array}$ & $\begin{array}{l}\text { Clear cell renal cell } \\
\text { carcinoma }\end{array}$ & 3 & $\begin{array}{l}\mathrm{pT} 1 \mathrm{~b}, \mathrm{Nx} \\
\mathrm{Mx}\end{array}$ & Clear \\
\hline 4 & 47 & $M$ & 2002 & $\begin{array}{l}\text { Left open partial } \\
\text { nephrectomy }\end{array}$ & $\begin{array}{l}\text { Clear cell renal cell } \\
\text { carcinoma }\end{array}$ & 3 & $\begin{array}{l}\mathrm{pT} 1 \mathrm{~b}, \mathrm{Nx} \\
\mathrm{Mx}\end{array}$ & Clear \\
\hline
\end{tabular}

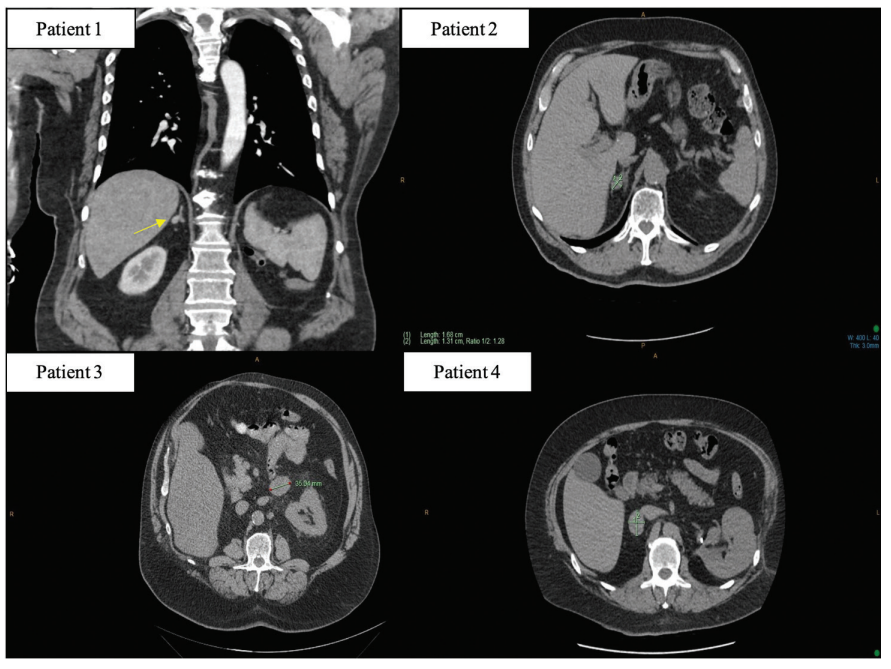

Figure 2. Computed tomography surveillance revealing solitary adrenal metastatic disease in the four patients, marked in yellow. Time of recurrence and size of the adrenal mass detected were highly variable among patients

No patients were reported to have had endocrine complications as a result of adrenalectomy during this period.

Table 4 lists the pathology of the excised adrenal glands. All tumors were consistent with metastatic clear cell RCC and International Society of Urologic Pathologists grade 3. All surgical margins were clear.

Oncological outcomes are summarized in Table 5. At the time of writing, three of the four patients are alive and remain disease-free. Two patients underwent adjuvant chemotherapy for suspected local recurrence identified on surveillance imaging. The patient who developed widespread metastatic disease approximately 20 months post-adrenalectomy died. This was discovered following a pathological fracture of the right femur. The patient underwent adjuvant chemotherapy and radiotherapy. From the time of diagnosis of the metastatic disease, the patient survived another 25 months before he died. The oncological outcomes of each patient are outlined in Table 5.

\begin{tabular}{|l|l|l|}
$\begin{array}{l}\text { Table 2. Detection of disease recurrence from initial } \\
\text { nephrectomy } \\
\text { Patient }\end{array}$ & $\begin{array}{l}\text { Time from nephrectomy } \\
\text { to identifiable adrenal } \\
\text { metastasis (months) }\end{array}$ & Computed tomography finding \\
\hline 1 & 15.5 & $\begin{array}{l}\text { 35-mm right contralateral } \\
\text { adrenal nodule }\end{array}$ \\
\hline 2 & 11.6 & $\begin{array}{l}\text { 29-mm right ipsilateral adrenal } \\
\text { nodule }\end{array}$ \\
\hline 3 & 89.6 & $\begin{array}{l}\text { 70-mm left contralateral } \\
\text { adrenal mass }\end{array}$ \\
\hline 4 & 152.3 & $\begin{array}{l}32-\mathrm{mm} \text { right contralateral } \\
\text { adrenal mass }\end{array}$ \\
\hline
\end{tabular}

Table 3. Perioperative outcomes of laparoscopic retroperitoneal adrenalectomy for metastatic RCC

\begin{tabular}{|l|l|l|l|l|l|l|}
\hline Patient & Side & Age & $\begin{array}{l}\text { BMI } \\
\mathbf{( k g /} / \\
\left.\mathbf{m}^{2}\right)\end{array}$ & $\begin{array}{l}\text { Operative } \\
\text { time } \\
(\mathbf{m i n})\end{array}$ & $\begin{array}{l}\text { Blood } \\
\text { loss } \\
(\mathbf{m L})\end{array}$ & $\begin{array}{l}\text { Length } \\
\text { of stay } \\
\text { (days) }\end{array}$ \\
\hline 1 & Right & 71 & 39 & 155 & 50 & 3 \\
\hline 2 & Right & 77 & 32 & 135 & 50 & 2 \\
\hline 3 & Left & 72 & 38 & 135 & 350 & 2 \\
\hline 4 & Right & 60 & 44 & 135 & 200 & 2 \\
\hline \multicolumn{7}{|l|}{ BMI: Body mass index, Min: Minimum, RCC: Renal cell carcinoma } \\
\hline
\end{tabular}

\section{Discussion}

In this case series at our institution, solitary adrenal metastatic RCC recurrence post-radical nephrectomy was rarely encountered. This is consistent with the published literature, in which retroperitoneal laparoscopic adrenalectomy for solitary adrenal RCC recurrence has not been well described. A dataset of a small series showed the safety of this procedure. Of interest, in our case series, the recurrence in three of the four patients found in the contralateral adrenal gland reflects the unpredictability of the disease. The underlying pathophysiology of why the RCC spread to the contralateral adrenal gland is unknown. It may be due to the rich blood supply of the organ in 


\begin{tabular}{|l|l|l|l|l|}
\hline \multicolumn{2}{|l|}{ Table 4. Histopathological outcomes following laparoscopic retroperitoneal adrenalectomy } \\
\hline Patient & Histopathology & ISUP grade & Tumor size (mm) & Surgical margins \\
\hline 1 & Metastatic clear cell renal cell carcinoma & 3 & $25 \times 15 \times 22$ & Clear \\
\hline 2 & Metastatic clear cell renal cell carcinoma & 3 & $25 \times 25 \times 27$ & Clear \\
\hline 3 & Metastatic clear cell renal cell carcinoma & 3 & $60 \times 45 \times 40$ & Clear \\
\hline 4 & Metastatic clear cell renal cell carcinoma & 3 & $45 \times 23 \times 13$ & Clear \\
\hline ISUP: International Society of Urologic Pathologists & & & \\
\hline
\end{tabular}

\begin{tabular}{|c|c|c|c|c|c|}
\hline Patient & Local disease recurrence & Distant disease recurrence & $\begin{array}{l}\text { Adjuvant chemotherapy or } \\
\text { radiotherapy }\end{array}$ & $\begin{array}{l}\text { Disease-free } \\
\text { survival (months) }\end{array}$ & $\begin{array}{l}\text { Overall } \\
\text { survival }\end{array}$ \\
\hline 2 & Nil & $\mathrm{Nil}$ & No & 35 & 35 \\
\hline 3 & $\begin{array}{l}\text { Left adrenal mass } 43 \times 39 \times 41 \\
\mathrm{~mm} \text { within the surgical } \\
\text { bed detected } 4 \text { months } \\
\text { postoperatively. No change } \\
\text { in size in } 4 \text { years of } \\
\text { surveillance }\end{array}$ & Nil & Chemotherapy & 4 & $\begin{array}{l}61 \text { months - } \\
\text { still alive }\end{array}$ \\
\hline 4 & Nil & $\begin{array}{l}\text { Widespread metastatic } \\
\text { disease - pathological } \\
\text { fracture of the right femur, } \\
\text { lytic lesions T8, T11, left } \\
\text { scapula, left femur, base of } \\
\text { the skull }\end{array}$ & $\begin{array}{l}\text { Chemotherapy and } \\
\text { palliative radiotherapy }\end{array}$ & 20 & 45 months \\
\hline
\end{tabular}

conjunction with a possible affinity of the RCC cells to adrenal tissues (11).

The nature of metastatic RCC is varied. Metastatic burden heavily influences survival. The mean survival in patients with heavy metastatic burden is approximately 11 months (12). In patients with solitary metastasis, approximately $30 \%$ are alive at 5 years (12). The role of local therapy for an oligometastatic disease is unclear. Utsumi et al. (13) reported that surgery for adrenal RCC metastasis achieved a curative outcome in 1 of 3 patients.

Although surgical management of solitary adrenal tumors from metastatic RCC is advocated, there is no clear evidence on how this should be performed-open or laparoscopic, and if minimally invasive, transperitoneal or retroperitoneal. Traditionally, open adrenalectomy was recommended for the treatment of malignant adrenal lesions. To our knowledge, no studies have compared retroperitoneal versus transperitoneal laparoscopic surgery in the management of solitary adrenal RCC metastasis. Studies of retroperitoneal against transperitoneal laparoscopic renal surgery have shown improved perioperative outcomes including blood loss, length of stay, and postoperative complications (14). This is hypothesized as caused by the earlier exposure of the critical anatomical structures gained in a retroperitoneal approach and lower risk of injuring intraperitoneal organs plus avoidance of adhesions from previous intra-abdominal surgery.

Several studies have now demonstrated comparable oncological and survival outcomes of laparoscopic and open adrenalectomy for patients with adrenal tumors, though not specifically related to the retroperitoneal approach $(15,16)$. In a metaanalysis comparing transperitoneal laparoscopic adrenalectomy with the retroperitoneal approach in the management of pheochromocytoma in 145 patients, Jiang et al. (16) found that that the retroperitoneal approach was superior (17). Patients who underwent retroperitoneal laparoscopic adrenalectomy were associated with shorter operating times, less intraoperative blood loss, and a shorter duration of stay in hospital. No difference was found in the postoperative complications between groups (16). Chai et al. (17) performed a systematic review comparing laparoscopic retroperitoneal, laparoscopic intraperitoneal, and robotic adrenalectomy for adrenal tumors, but not specifically for solitary adrenal RCC metastasis. The review suggested that the laparoscopic retroperitoneal approach was superior (17). In this study, the perioperative outcomes demonstrated that this technique is associated with minimal blood loss and short operating time and length of stay. To our knowledge, no studies have compared the oncological outcomes and survival of patients who have undergone laparoscopic retroperitoneal adrenalectomy with other approaches. Survival outcomes 
at 5 years following removal of a solitary adrenal metastasis from RCC varied between $14 \%$ and $38 \%$ (18). A systematic review comparing disease-free survival, local recurrence, and mortality between laparoscopic and open adrenalectomy for adrenocortical carcinoma found no difference in these outcomes (19).

Despite the rapid advancements in systemic chemotherapeutic therapies for metastatic RCC, reports of long-term disease-free survival for metastatic RCC are limited. Thus, the finding that 3 of 4 patients treated surgically for oligometastatic RCC remain recurrence-free at the time of this study is promising.

To our knowledge, this is the largest case series of laparoscopic retroperitoneal adrenalectomy for solitary RCC metastasis to the adrenal gland. Our case series reports perioperative and oncological outcomes over a median follow-up of 40 (20-53) months. This study shows the technique to be safe with diseasefree survival comparable with published literature for other extirpative techniques.

\section{Study Limitations}

This retrospective case series study provides data on a rare clinical scenario managed by a surgical approach not widely utilized. This study does not answer what is the optimal management strategy for solitary RCC metastasis to the adrenal gland. Nor does it provide evidence for this technique over other surgical techniques in those electing for surgical intervention.

Although three of the cases were performed partly by trainees, the operating time, blood loss, low perioperative complication rate, length of stay, and absence of positive margins suggest that this is a reproducible technique even for metastatic disease in the adrenal gland. Ideally, larger, prospective randomized studies will need to be undertaken to evaluate and compare this technique against others-transperitoneal, open, and robotassisted techniques. However, these studies are difficult to perform prospectively given the rare nature of isolated adrenal RCC metastasis.

\section{Conclusion}

In this study, we have shown that laparoscopic retroperitoneal adrenalectomy is a safe procedure for the management of solitary adrenal metastatic disease from RCC. Although this is a small series with no control arm, the oncological outcomes are encouraging. Thus, randomized trials are needed to assess the optimal management for solitary RCC metastasis to the adrenal gland, in which surgical technique is optimal.

\section{Ethics}

Ethics Committee Approval: Ethics approval was obtained from the Hunter New England Human Research Ethics Committee in conjunction with the Central Coast Local Health District (2020/ ETH02908).

Informed Consent: Retrospective study.

Peer-review: Externally peer-reviewed.

\section{Authorship Contributions}

Surgical and Medical Practices: G.A., M.L.J., Concept: C.P., M.L.J., Design: C.P., M.L.J., Data Collection or Processing: C.P., M.L.J., Analysis or Interpretation: C.P., G.A., M.L.J., Literature Search: C.P., Writing: C.P., G.A., M.L.J.

Conflict of Interest: No conflict of interest was declared by the authors.

Financial Disclosure: The authors declare that they have no relevant financial.

\section{References}

1. Australian Institute of Health and Welfare. Cancer in Australia 2019 (2019). Cancer series no.119. Cat. No. CAN 123. Canberra: AlHW.

2. Siegel R, Ward E, Brawley O, Jemal A. Cancer statistics, 2011: the impact of eliminating socioeconomic and racial disparities on premature cancer deaths. CA Cancer J Clin 2011;61:212-236.

3. Pantuck AJ, Zisman A, Belldegrun AS. The changing natural history of renal cell carcinoma. J Urol 2001;166:1611-1623.

4. Lau WK, Zincke H, Lohse CM, Cheville JC, Weaver AL, Blute ML. Contralateral adrenal metastasis of renal cell carcinoma: treatment, outcome and a review. BJU Int 2003;91:775-779.

5. Ip JCY, Lee JC, Sidhu SB. Laparoscopic Adrenalectomy: The Transperitoneal Approach. Current Surgery Reports 2012;1:26-33.

6. Mihai R. Open adrenalectomy. Gland Surg 2019;8(Suppl 1):S28-S35.

7. Walz MK, Alesina PF, Wenger FA, Deligiannis $A$, Szuczik $E$, Petersenn $S$, Ommer A, Groeben H, Peitgen $K$, Janssen OE, Philipp T, Neumann HP, Schmid KW, Mann K. Posterior retroperitoneoscopic adrenalectomy--results of 560 procedures in 520 patients. Surgery 2006;140:943-948.

8. Lee CR, Walz MK, Park S, Park JH, Jeong JS, Lee SH, Kang SW, Jeong JJ, Nam $\mathrm{KH}$, Chung WY, Park CS. A comparative study of the transperitoneal and posterior retroperitoneal approaches for laparoscopic adrenalectomy for adrenal tumors. Ann Surg Oncol 2012;19:2629-2634.

9. Alesina PF. Retroperitoneal adrenalectomy-learning curve, practical tips and tricks, what limits its wider uptake. Gland Surg 2019;8(Suppl 1):S36-S40.

10. Chen W, Lin W, Han DJ, Liang Y. Lateral retroperitoneoscopic adrenalectomy for complicated adrenal tumor larger than 5 centimeters. Afr Health Sci 2017;17:293-300.

11. Sagalowsky Al, Kadesky KT, Ewalt DM, Kennedy TJ. Factors influencing adrenal metastasis in renal cell carcinoma. J Urol 1994;151:1181-1184.

12. Silverman SG, Gan YU, Mortele KJ, Tuncali K, Cibas ES. Renal masses in the adult patient: the role of percutaneous biopsy. Radiology 2006;240:6-22.

13. Utsumi T, Suzuki H, Nakamura K, Kim W, Kamijima S, Awa Y, Araki K, Nihei $N$, Naya $Y$, Ichikawa T. Renal cell carcinoma with a huge solitary metastasis to the contralateral adrenal gland: a case report. Int J Urol 2008;15:10771079.

14. Hatano K, Horii S, Nakai Y, Nakayama M, Kakimoto KI, Nishimura K. The outcomes of adrenalectomy for solitary adrenal metastasis: A 17-year single-center experience. Asia Pac J Clin Oncol 2020;16:e86-e90. 
15. Sarela Al, Murphy I, Coit DG, Conlon KC. Metastasis to the adrenal gland: the emerging role of laparoscopic surgery. Ann Surg Oncol 2003;10:11911196.

16. Jiang $Y L$, Qian L, Li Z, Wang KE, Zhou XL, Zhou J, Ye CH. Comparison of the retroperitoneal versus Transperitoneal laparoscopic Adrenalectomy perioperative outcomes and safety for Pheochromocytoma: a metaanalysis. BMC Surg 2020;20:12.

17. Chai YJ, Kwon H, Yu HW, Kim SJ, Choi JY, Lee KE, Youn YK. Systematic Review of Surgical Approaches for Adrenal Tumors: Lateral Transperitoneal versus
Posterior Retroperitoneal and Laparoscopic versus Robotic Adrenalectomy. Int J Endocrinol 2014;2014:918346.

18. Zografos GN, Farfaras A, Aggeli C, Kontogeorgos G, Pagoni M, Vogiati S, Vasiliadis G, Papastratis G. Laparoscopic adrenalectomy for large adrenal metastasis from contralateral renal cell carcinoma. JSLS 2007;11:261-265.

19. Machado NO, Al Qadhi H, AI Wahaibi K, Rizvi SG. Laparoscopic Adrenalectomy for Large Adrenocortical Carcinoma. JSLS 2015;19:e2015.00036. 